\title{
Geomorphic Evaluation of Valley of Flower Region Bhyunder Ganga Catchment, Chamoli District, Uttarakhand Using: Remote Sensing \& GIS Technology
}

\author{
Khanduri Kamlesh \\ D. Phil Research Scholar, Dpt. of Geography, HNBGU, JRF, FSI, Dehradun, Uttrakhand, India \\ E-mail: ecnhas@gmail.com
}

Singh Avtar, Singh Prabhbir \& Tiwari Kuldeep

Technical Associate (JRF), Forest Survey of India (FSI), Dehradun, Uttrakhand, India

\author{
Received: August 24, 2011 Accepted: September 21, $2011 \quad$ Published: February 1, 2012 \\ doi:10.5539/esr.v1n1p114 URL: http://dx.doi.org/10.5539/esr.v1n1p114
}

\begin{abstract}
Geomorphology is the science of evolution of landforms in terms of its lithology, structures, basin geometry and other morphometric factors. In this small study, various gemorphological parameters are covering the Bhyunder Ganga Catchment. The main object is to map the land system into further various Landform unit and features through geomorphic approach in Bhyunder Ganga Catchment. Geomorphologic maps were prepared using Satellite images (Landsat ETM+, TM, MSS, ASTER, SRTM) and digital SOI topographic sheet of the region; this was further updated during post field work. Digital Elevation Model (DEM) generation based on topographical sheet was prepared for creating relief map, slope map, aspect map and 3D visualization in addition to drainage map with the help of topographical sheets, the generation of various thematic layers has also been developed. Land Use/Cover over the study area has been analyzed for the time periods of 2008 .The major proportion in land use is the snow cover (53.20\%). Other landuse are barren land (22\%), dense forest, open forest, built up and water bodies occupy only $24.8 \%$ area of catchment. Various theme maps (erosion intensity, LST) were generated for GIS study analysis is done to analyze the instability and morphology of the catchment area.
\end{abstract}

Keywords: DEM, Geomorphology, GIS \& Remote Sensing, LST

\section{Introduction}

The valley of flower is situated in Bhyunder Ganga catchment raises from Tipra Bamak in the north and Dang Kharak Chainyal Kharak glaciers in the east. Valley of flower is also known as the Pushpawati national park after the river of that name which flows through the famous high altitude valley of flowers (Negi Sharad, 1992). Bhyunderganga is the fifth order major tributary of river Alaknanda. The quaternary sediments are mainly exposed in the form of terraces, old fan terraces, glacio-fluvial fan and moraine in the Bhyunder Valley. This catchment is heavily glaciated and the features like cirques, horn peaks, and hanging valleys. In Bhyunder Valley number of erosional and depositional terraces is well exposed and can be seen near Bhyunder Village. Bhyunder Ganga is a glacial fed (Tipra Bamak Glacier) having higher gradient that joins with another major fifth order tributary (fed by Dang glacier and Chainyal Glaciers) in its downstream at Bhyunder Village.

Its central valley, lying at about $3,500 \mathrm{~m}$, is a gently inclined basin of some 1,000 hectares of alpine meadows, known as the Kundalinisen plateau, the forested slopes of which rise sharply through moraines to rocky ridges, perpetually snow-covered peaks and glaciers which together cover $73 \%$ valley. Alpine meadows cover $21 \%$ and forest $6 \%$ of the rest catchment areas (UNESCO, UNEP, 2005). The valley of flower section of the Bhyunderganga is a dissected outwash plain and glacial fan. Most of the third and fourth order tributaries meet at right angle to the Bhyunderganga River that follows NW - SW direction. After covering its length $19 \mathrm{~km}$ course Bhyunderganga joins Alaknanda near Govindghat. The catchment area consists in the total region of protector rising high grade metamorphic rocks of central crystallines. This consists of the Pandukeshwar and Joshimath formations. 


\section{Study Area}

The Bhyunder Ganga valley which is one of the important valleys in the Himalayan Ganga System has an area of 137.6 sq. km., Bhyunder Ganga catchment lying between $79^{\circ} 35^{\prime} 00^{\prime \prime}-79^{\circ} 42^{\prime} 00^{\prime \prime}$ East to $30^{\circ} 38^{\prime} 00^{\prime \prime}-30^{\circ} 45^{\prime} 00^{\prime \prime}$ North. It is situated Chamoli Garhwal District in Uttarakhand State. Figure 1 depicts location map of Bhyunder Ganga.

\begin{tabular}{|l|l|l|}
\hline Area $\mathbf{k m}^{2}$ & Surface area (3D) $\mathbf{k m}^{\mathbf{2}}$ & $\mathbf{K m}^{\mathbf{3}}$ \\
\hline 137.6 & 377.0 & 308.5 \\
\hline
\end{tabular}

\section{Methodology}

Methodology is a sequence of activities that starts with the decision making, problem recognition and ends with recommendation. The quality of decision making depends on sequence on which the activities are undertaken. The details of the methodology are described below.

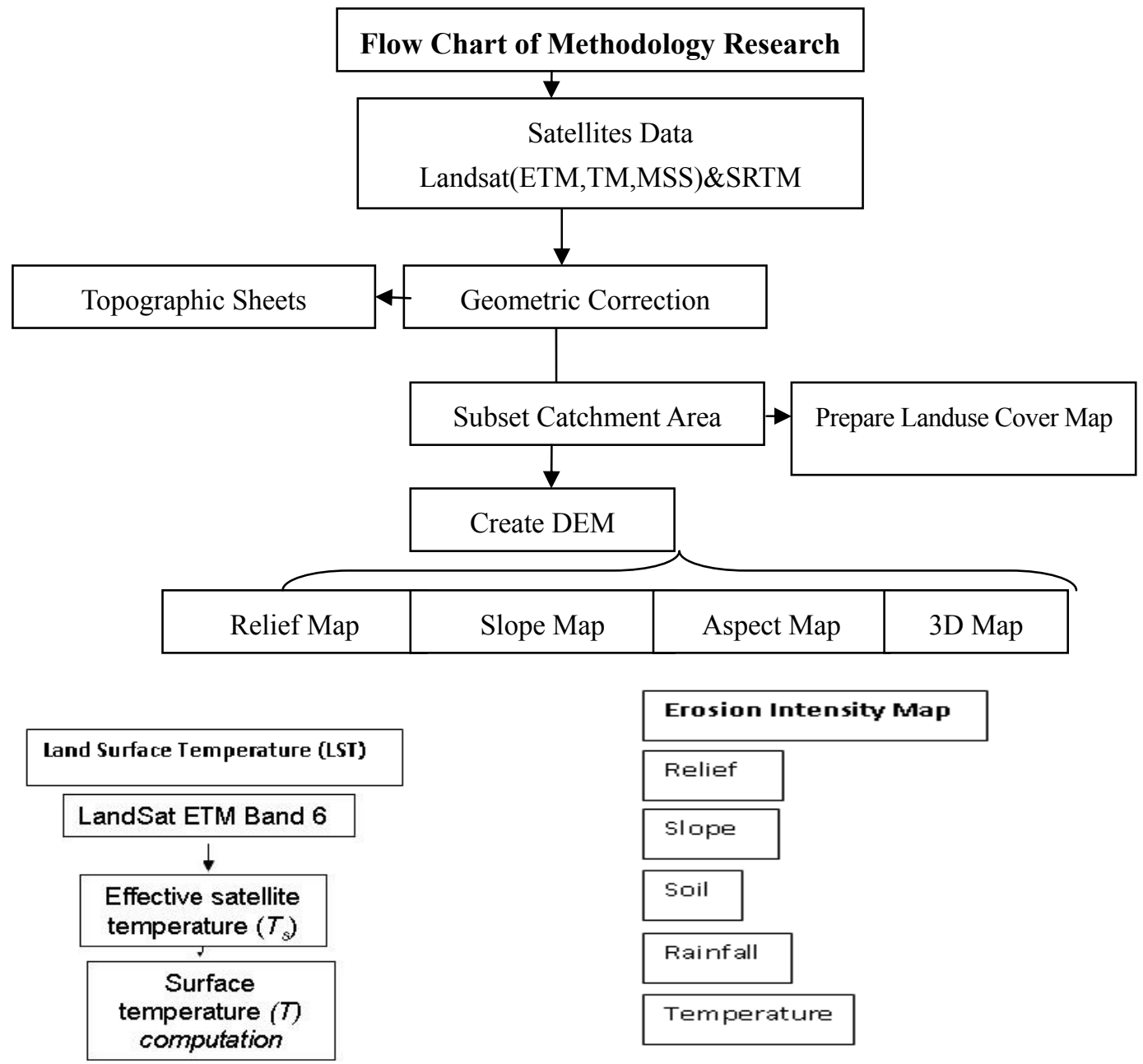

\section{Results \& Discussions}

This study Based on a brief reconnaissance survey with additional information from previous research in the study area, a classification scheme was developed for the study area after Anderson et al. (1967). The classification scheme developed gives a rather broad classification where the land use, LST and DEM were identified by a single digit. The results are presented in form of maps, charts and statistical tables.

\subsection{Relief and slope classification of study area}

Relief of Bhyunder Ganga Basin varies between 1750-6745m. Slope maps were prepared from the digital elevation model DEM and topographic map of hazards. Here slope has been classified into six classes: i) $0-10^{0}$, ii) $10-20$, iii) $20-35^{\circ}$, iv) $35-50^{\circ}$, v) $50-65^{\circ}$ and vi) $65-$ to above. Table 1 and Figure 2 show relief $\&$ slope classification of Bhyunder Ganga. The slope is the gradient of the land, and is generally expressed in percent or 
degree. Highly sloping terrain accelerate the spread High Himalayan environment of the Bhyunderganga catchment maintain its distinctiveness for steep slopes above $50^{\circ}$ representing $24.7 \%$ area of the catchment against $7.2 \%$ of the whole Alaknanda Basin(Khanduri, 2011). Nearly $80 \%$ area of the catchment exhibit features activated with high altitude environment above tree line.

\subsection{Land surface temperature (LST) classification}

The classified Landsat TM (Thematic Layer) imagery of April-May 1990-2005 indicates an obvious gradual thermal change or LST. Wasteland and vacant land have also highest LST $\left(22^{\circ} \mathrm{C}-24^{\circ} \mathrm{C}\right)$. The vegetation covers area, water bodies and cultivated land have the least with $\left(14^{0} \mathrm{C}-22^{\circ} \mathrm{C}\right)$. With the help of LST analysis it is found that temperature increase by $0.75^{\circ} \mathrm{C}$ in the 25 years (1990-2005). Table 2 and Figure 3 depicts the Land Surface temperature (LST) change for the year 1990-2005 in Bhyunder Ganga Catchment area.

\subsection{Landuse \& landcover classification}

Land use and land cover mapping of Bhyunder Ganga has been carried out standard methods of analysis of remotely sensed data and followed by ground truth collection and interpretation of satellite data. Land use planning participants in the LUP approaches. Here land use (LUP) approach requires more and more data integration, multi-disciplinary and complex analysis, and need faster or more precise information (CISMHE, Delhi) .Land cover \& land use mapping are given below in Table $3 \&$ Figure 4.

\subsection{Erosion intensity classification}

Erosion intensity highly precisely and process erosion classification of the Remote Sensing images highly efficiently. The thematic map could be prepared in a shorter period than manual processing with the help of GIS analysis technique (Hao Jie, 2002). The present erosion intensity zone analysis has categorized into six different zones i.e. Very High, High, Moderate, Medium, Gentle and Very Gentle. Very high zone is covering $10.43 \%$ of the total area. $25.67 \%$ and $29.87 \%$ area is included in high and moderate zone, whereas very gentle erosion zone and gentle zone has $33.85 \%$ of the total area. Thus, the erosion intensity prone zones are depicted below in Figure 5.

\section{Conclusion}

Thus from the above small study it is observed that geomorphological study has several advantages. It will be of great use to policy makers, rural planners, in preparing proper village plans, slope stability plan, disaster management plan and prevention, for drainage designers to layout drains conforming to the contours of the area, hydro electric probabilities as well as creation of other infrastructure facilities like laying out of roads, national parks reserve forest, tourist lodge, laying of electricity lines, water delivery structures and many more projects and Government Plans.

\section{Acknowledgement}

Authors are thankful to Prof. Kamlesh Kumar (Rtd.), Dpt. of Geography, HNBGU, Srinagar, Uttrakhand for his suggestion and necessary improvement at the final stage of this paper.

\section{References}

Agrawal Devendra, Mahendra S. Lodhi and Shradha Panwar. (2010). Are EIA studies sufficient for projected Hydropower development in the Indian Himalayan region. Current Science, 98, 2-25.

Centre for Inter-Disciplinary Studies of Mountain \& Hill Environment. (2008). Environmental Impact \& Management Plan for Alaknanda H. E. Project, Uttarakhand. CISMHE. [Online] Available at: http://envfor.nic.in/divisions/iass/Executive\%20Summary.pdf.

Khanduri Kamlesh. (2007-2011). A Geographical Study of Hazards \& Disaster Management in Uttrakhand: With Reference to Chamoli District. Unpublished D. Phil Thesis, H.N.B.G. University.

Mohan, J. D. Giri and R. L. Shyampura. (2006). 3DVisualization of Udaipur City and its Environs. Indian Cartographer, 104-105.

Smythe, F. (1998). The Valley of Flowers. Newyork.

Srivastava, S. (1999). Management Plan for Valley of Flowers National Park. Wildlife Preservation Org. Uttarpradesh. [Online] Available at: http://www.eoearth.org/article/Nanda_Devi_and_Valley_of_Flowers_National_Park 
Table 1. Bhyunder Ganga Relief and Slope Classification

\begin{tabular}{|l|l|l|l|}
\hline Height in $(\mathrm{m})$ & Percent \% & Slope in Degree & Percent \% \\
\hline Below -4500 & 33.10 & Below -10 & 4.50 \\
\hline $4500-5000$ & 21.35 & $10-20$ & 9.85 \\
\hline $5000-5500$ & 8.07 & $20-35$ & 24.00 \\
\hline $5500-6000$ & 2.28 & $35-50$ & 36.96 \\
\hline Above -6000 & 0.80 & $50-65$ & 19.77 \\
\hline & & Above -65 & 4.92 \\
\hline
\end{tabular}

Table 2. Bhyunder Ganga Land Surface Temperature (LST) Classification

\begin{tabular}{|l|l|l|}
\hline Class (Temp. in $\left.\mathrm{C}^{0}\right)$ & $\begin{array}{l}\text { Bhyunder Ganga Temp. } \\
\text { April-May 1990 (\%) }\end{array}$ & $\begin{array}{l}\text { Bhyunder Ganga Temp. } \\
\text { April-May 2005 (\%) }\end{array}$ \\
\hline Below -10 & 52.40 & 52.50 \\
\hline $10-15$ & 19.83 & 20.21 \\
\hline $15-20$ & 15.61 & 16.10 \\
\hline $20-25$ & 10.37 & 10.40 \\
\hline Above -25 & 1.78 & 1.90 \\
\hline
\end{tabular}

Table 3. Landuse Classification of Bhyunder Ganga

\begin{tabular}{|l|l|}
\hline Landuse Class & Bhyunder Ganga\% \\
\hline Dense forest & 9.82 \\
\hline Open forest & 6.93 \\
\hline Scrub land & 2.31 \\
\hline Barren land & 22.00 \\
\hline Agricultural land & 0.30 \\
\hline Grassland & 5.20 \\
\hline Snow covered & 53.20 \\
\hline
\end{tabular}




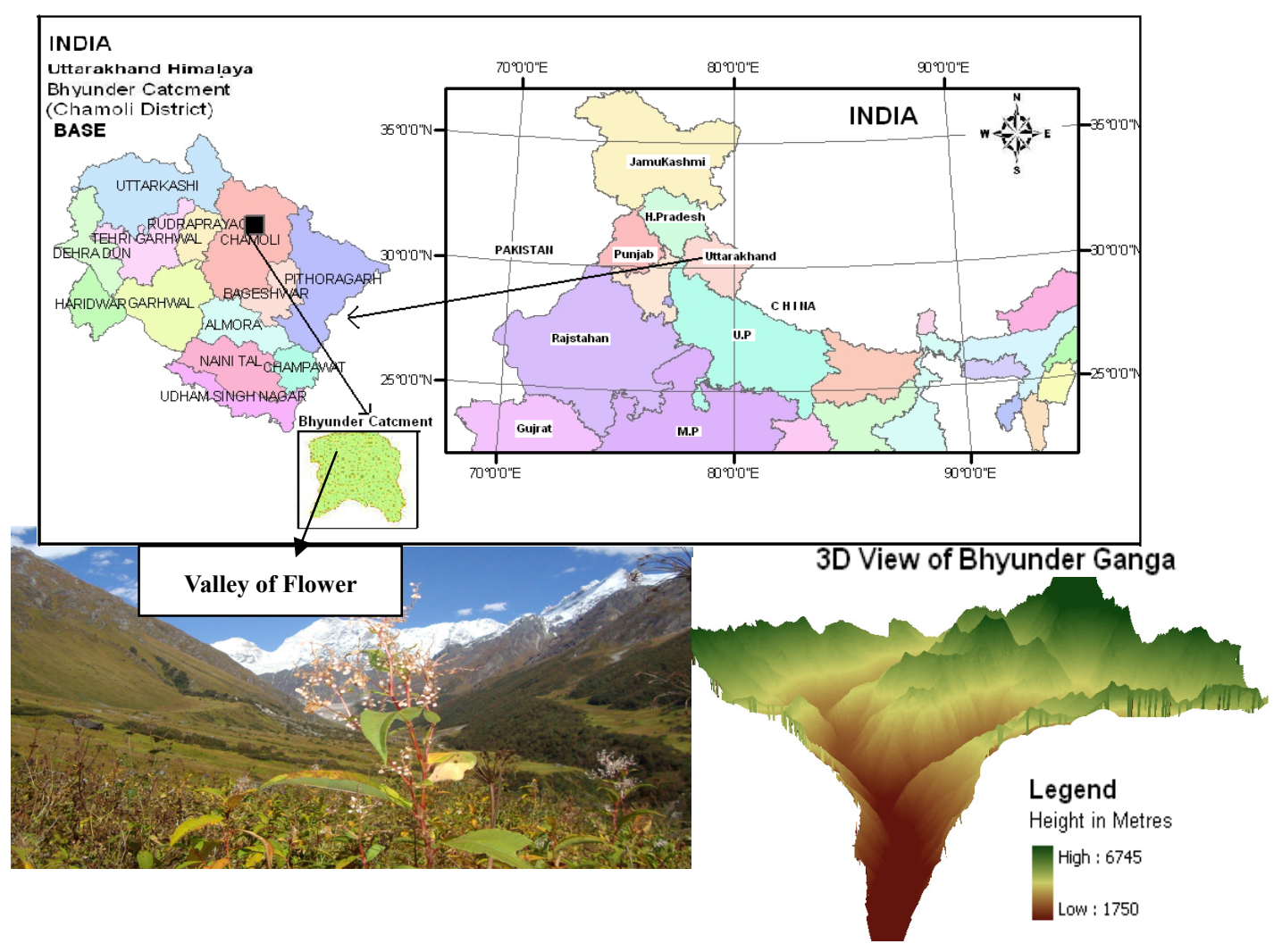

Figure 1. Location Map of Study
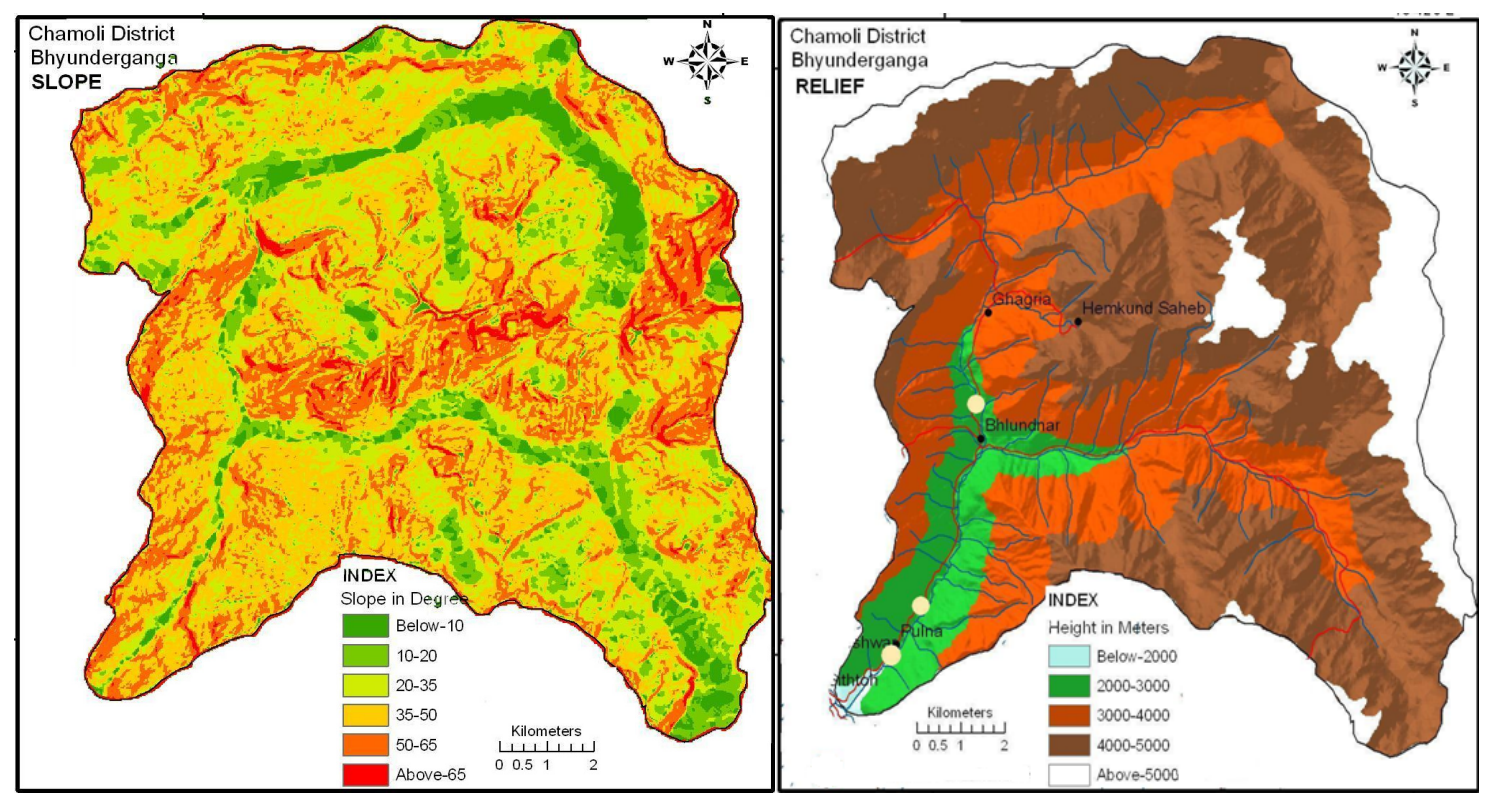

Figure 2. Relief \& Slope Classification of Catchment Area 

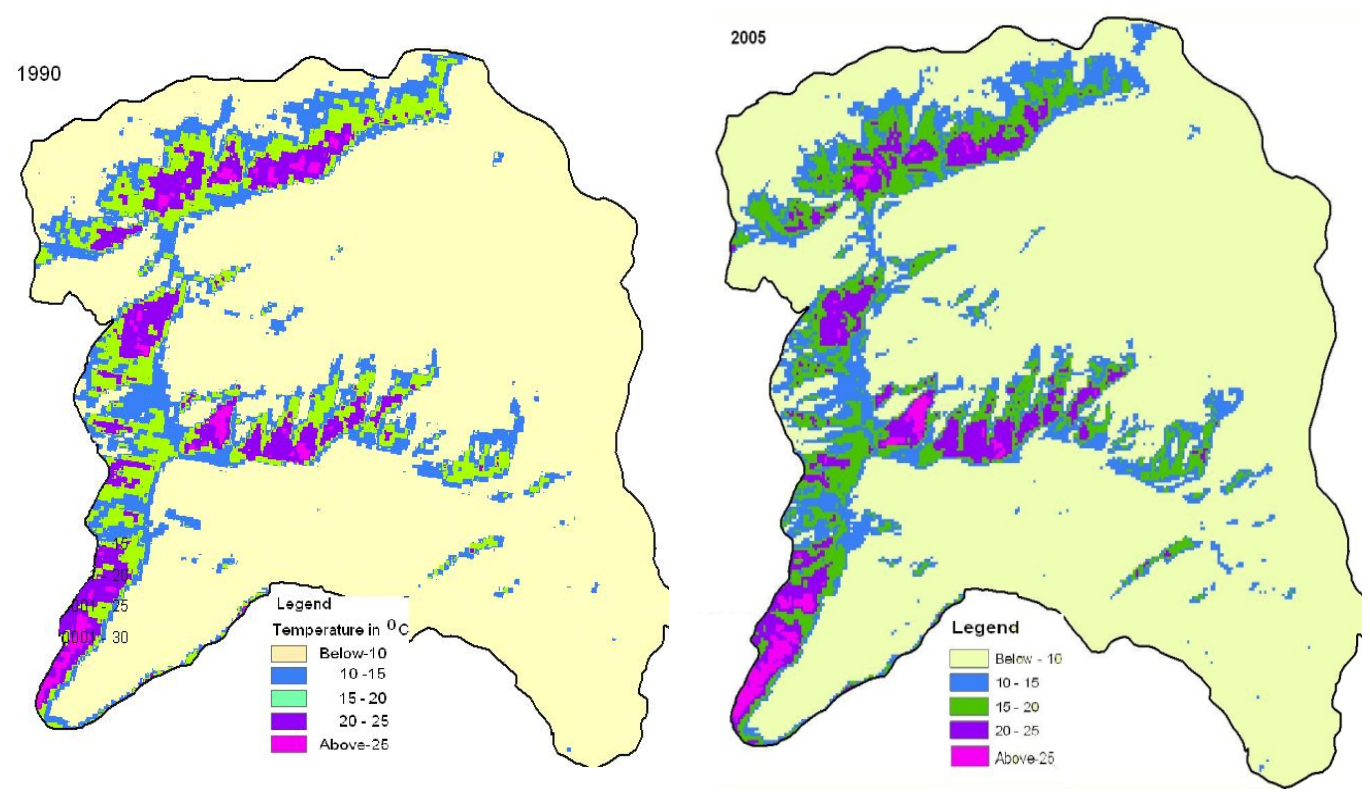

Figure 3. Land Surface Temperature of Study Area

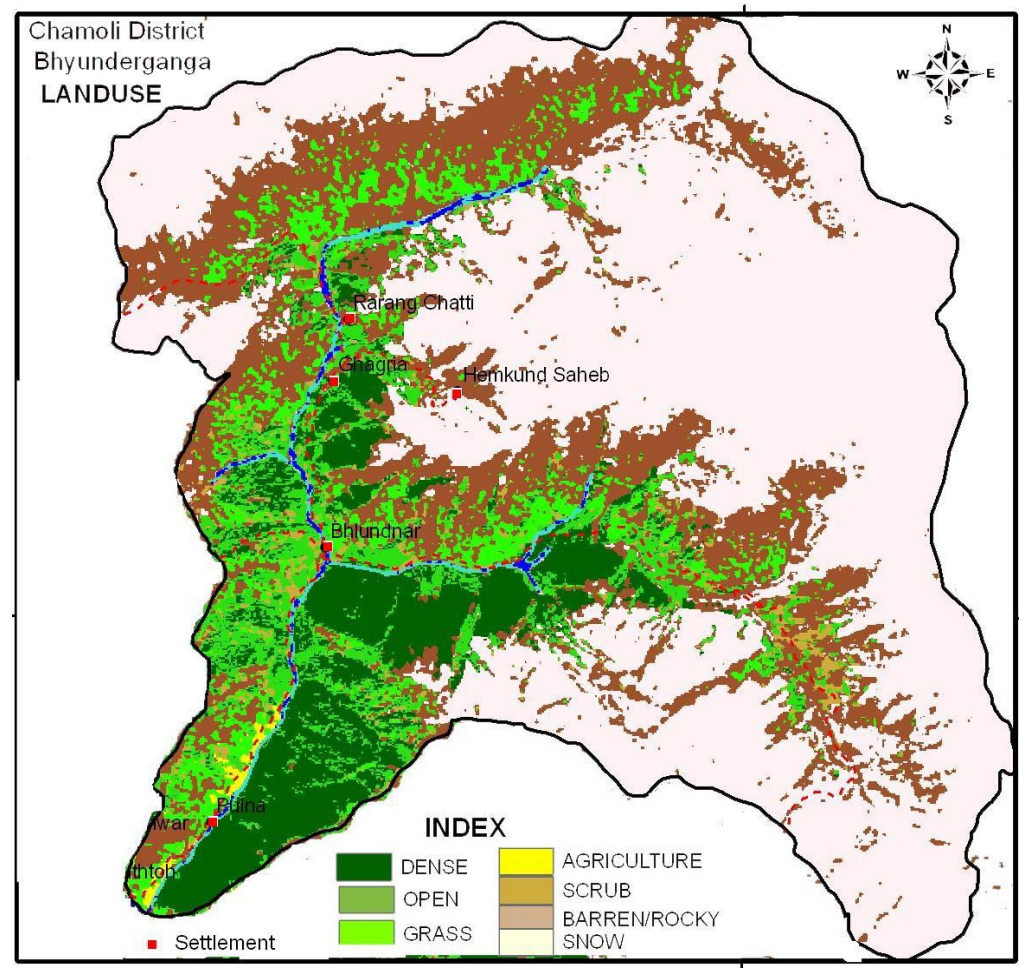

Figure 4. Landuse Categories for the year 2005 


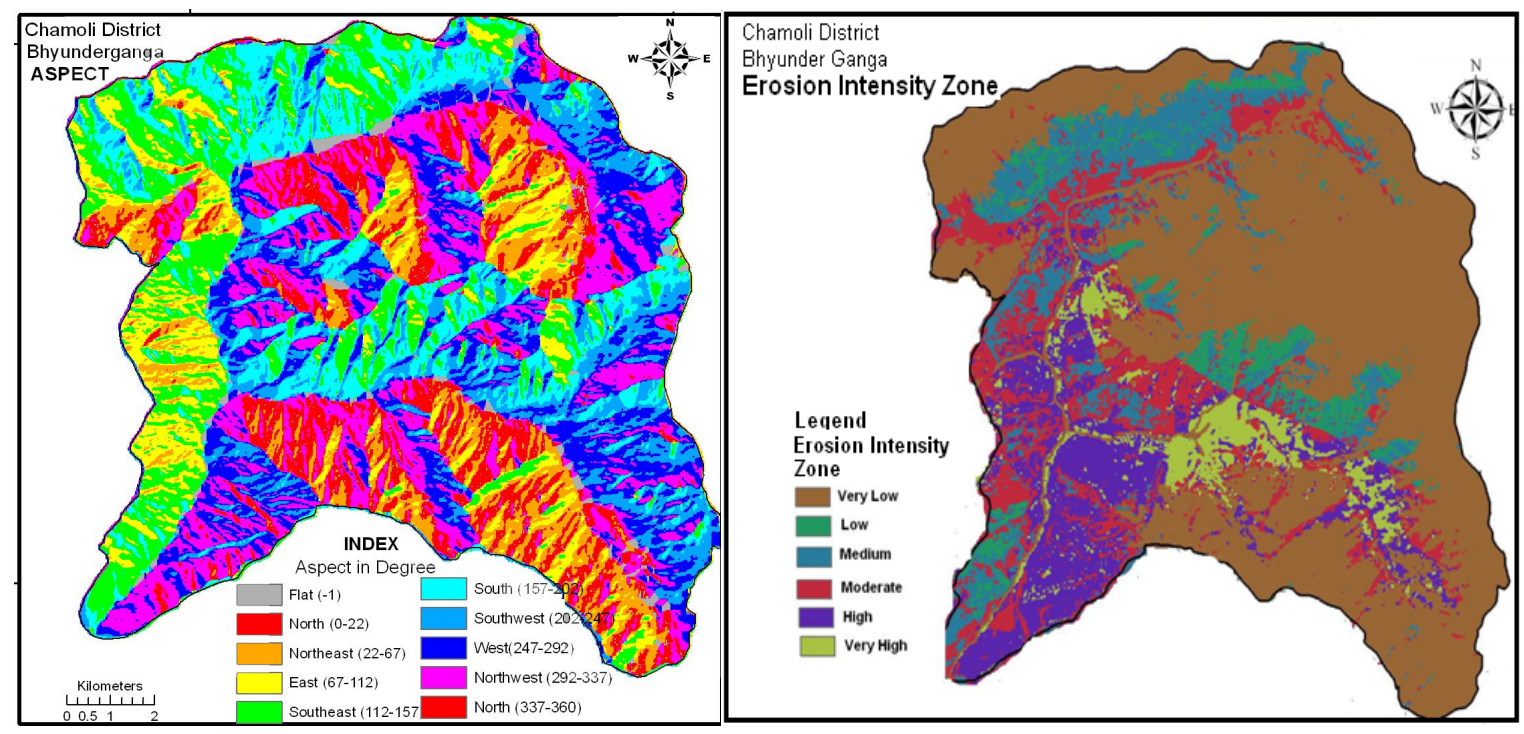

Figure 5. Aspect and Erosion Intensity Classification of Catchment 